\title{
REVIEW
}

\section{Genetics and genomics of radiotherapy toxicity: towards prediction}

\author{
Catharine M West*1 and Gillian C Barnett ${ }^{2}$
}

\begin{abstract}
Radiotherapy is involved in many curative treatments of cancer; millions of survivors live with the consequences of treatment, and toxicity in a minority limits the radiation doses that can be safely prescribed to the majority. Radiogenomics is the whole genome application of radiogenetics, which studies the influence of genetic variation on radiation response. Work in the area focuses on uncovering the underlying genetic causes of individual variation in sensitivity to radiation, which is important for effective, safe treatment. In this review, we highlight recent advances in radiotherapy and discuss results from four genomewide studies of radiotoxicity.

Keywords Radiation, radiotherapy, radiogenomics, single nucleotide polymorphism, genome-wide association study
\end{abstract}

\section{Introduction}

Since the discovery of radiation at the end of the 19th century, radiotherapy has become one of the most important modalities for treating cancer. The schedules (total radiation dose, dose per fraction, number of fractions, overall treatment time and volume irradiated) have been developed to maximize tumor kill and minimize normal tissue damage. The radiation dose prescribed depends on the cancer type and surrounding normal tissue tolerance. Doses are generally given so that $<5 \%$ of patients suffer serious toxicity up to 5 years following radiotherapy [1,2]. Serious side effects such as bowel obstruction and incontinence can occur months to years after treatment, be extremely debilitating and impact negatively on the quality-of-life of cancer survivors.

*Correspondence: catharine.west@manchester.ac.uk

'School of Cancer and Enabling Sciences, The University of Manchester, Manchester Academic Health Science Centre, The Christie, Wilmslow Road, Manchester M20 4BX, UK

Full list of author information is available at the end of the article
Given the millions of cancer survivors worldwide, estimated at 2 million in the UK and 12 million in the USA, there is a need to increase our understanding of the molecular pathogenesis of radiotherapy toxicity, find ways of predicting those patients likely to suffer with long-term side effects, and develop new approaches for their amelioration. As there is a direct relationship between radiation dose and tumor control, the development of side effects in a minority limits the dose that can be safely prescribed to the majority of patients. Development of a test to predict those likely to suffer side effects should enable individualized radiation dose prescription to increase cancer cure while reducing the number of survivors suffering with the consequences of treatment.

In this review, we outline the current radiotherapy approaches and understanding of how this treatment works. Then we discuss toxicity and the importance of genetics. We then focus on recent developments in identifying the genetic variants underlying radiosensitivity and the results from the first genome-wide association studies (GWASs), which suggested that a polymorphism in the follicle-stimulating hormone receptor (FSHR) gene might be associated with erectile dysfunction in AfricanAmerican men after radiotherapy for prostate cancer [3] and variants in PRDM1 with second cancer induction following radiotherapy for Hodgkin's lymphoma [4].

\section{Radiotherapy for cancer}

Around half of cancer patients receive radiotherapy [5], with an estimated $40 \%$ cured by radiotherapy compared with $49 \%$ by surgery and $11 \%$ by chemotherapy [6]. For some cancers of the head and neck, lung, cervix, bladder and prostate, radiotherapy can be used instead of surgery to achieve similar cure but with better functional results (for example, voice preservation for larynx cancers). For locally advanced cancers unsuitable for surgery, it is usually the only potentially curative option (for example, cervix). It is used neo-adjuvantly to shrink tumors prior to surgery (for example, rectal) and adjuvantly following surgery to target local microscopic spread of disease (for example, breast). As few tumors are cured by chemotherapy alone, improving the results of radiotherapy would impact significantly on cancer survival statistics. 


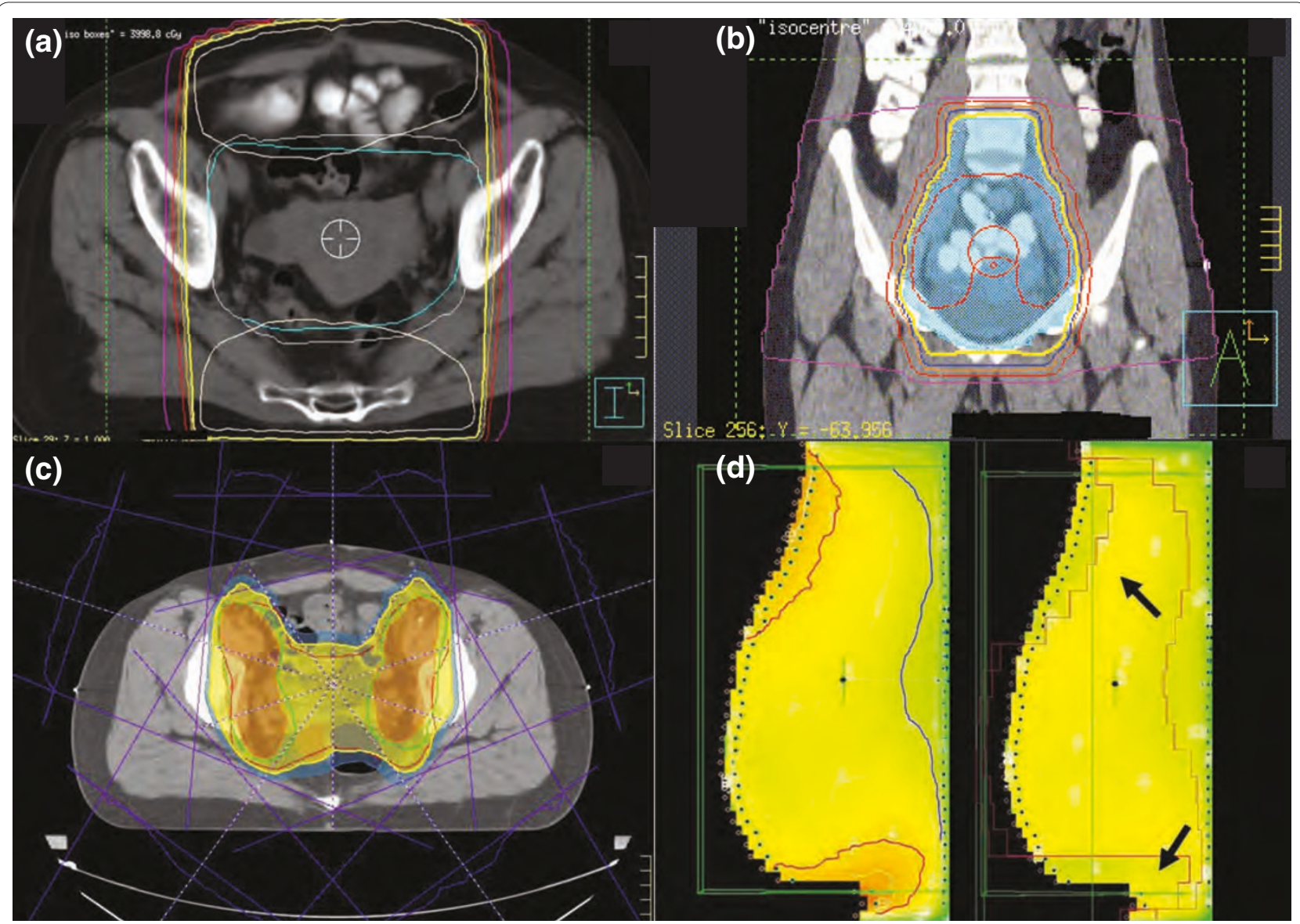

Figure 1. Radiotherapy for cancer. (a) Treatment plan for a cervix tumor from 1990 with radiation delivered as two fields from the front and back - parallel opposed pair - with the gantry of the linear accelerator moving to deliver high energy X-rays from different directions. A large rectangular volume, including the central uterus containing the tumor, parts of the bowel (top) and the base of the spine (bottom), received the maximum planned dose. (b) Treatment plan for a cervix tumor from 2011 with radiation delivered as four fields (front, back, both sides) and multileaf collimators (metal leaves that move independently to block the path of the beam) to shape (conform) the maximum radiation dose not only around the large tumor but also to follow the lymph node chains where the disease had spread, while sparing as much normal tissue as possible. (c) Treatment plan from 2011 to treat pelvic sidewall disease following surgical resection for a cervix tumor. The intensity modulated radiotherapy was given as eight fields, with radiation intensity modulated along the beams using multileaf collimators to deliver the maximum dose to the tumor and to spare normal tissue. (d) Intensity modulated radiotherapy for a breast tumor. Examples of uneven radiation dose distribution using standard two-dimensional radiotherapy (left). The orange color depicts regions of unwanted high dose, superiorly and inferiorly. There is also an unwanted low-dose region depicted in green. Changing to intensity-modulated radiotherapy evens the dose distribution across the breast, as shown by the more homogeneous yellow color (right).

Radiotherapy outcomes are improving because of technical developments allowing better radiation delivery to reduce the amount of normal tissue irradiated. Further gains will require a better understanding of molecular mechanisms and personalized treatment based on an individual patient's biology.

\section{Current radiotherapy approaches}

The two main approaches are external beam radiotherapy (EBRT) and brachytherapy. EBRT is used most widely and involves radiation delivered from a machine outside the body (usually high energy $\mathrm{X}$-rays from a linear accelerator). Radiation is given from different angles by moving the linear accelerator gantry so that multiple beams converge on a tumor. The area irradiated is determined by tumor imaging before treatment, and a target volume delineated to which margins are added to allow for microscopic spread and tumor movement. Until recently EBRT was planned in two dimensions and the radiation beam delivered from just a few angles (front and back, and sometimes both sides) with large box/ rectangular fields including adjacent normal tissues (Figure 1). With the development of computed tomography $(\mathrm{CT})$ and computers, tumors are now delineated 
in three dimensions using conformal radiotherapy where beams are shaped using metal plates (multileaf collimators) to shield normal tissue. EBRT is usually given as a course of multiple fractions, for example, 33 fractions of 2 grays (Gy; the standard unit of absorbed radiation dose) given Monday to Friday over 6 to 7 weeks. Fractionation maximizes tumor kill and minimizes normal tissue damage. The number and size of fractions are tumor type and stage specific but the schedules vary between centers and countries.

Brachytherapy involves placing radiation sources (radioactive seeds, needles, wires, pellets) into the body, within or close to a tumor. It is the treatment of choice in some centers for some breast and prostate cancers, and in most centers for locally advanced gynecological cancers. Different types of radioactive material are used. Radiation is also given systemically for some cancers as part of standard treatment, for example, radioactive iodine for some thyroid cancers [7] and radioimmunotherapy (monoclonal antibodies conjugated with radionuclides) for some lymphomas [8].

\section{New and emerging radiotherapy approaches}

Technical developments are improving the delivery of radiation (Figure 1). One technique used increasingly [9] is intensity-modulated radiotherapy (IMRT), where doses are varied along multiple beams using multileaf collimators to allow shaping to concave targets [10-13]. Evidence for the benefit of IMRT is now compelling [14], for example, randomized studies showing that IMRT reduces toxicity in head and neck $[15,16]$ and breast $[17,18]$ cancer. Another new approach being introduced is image-guided radiotherapy (IGRT) $[19,20]$. In IGRT, tumor motion can be tracked using radio-opaque markers implanted in or near a tumor. Changes in tumor position, size and shape during and between treatment fractions can therefore be monitored. This movement can be accounted for to improve the geometric accuracy of radiotherapy delivery and reduce volumes irradiated in shrinking tumors to spare normal tissues [21].There is an increasing diversity of IGRT approaches available from the different companies who manufacture linear accelerators. Stereotactic radiotherapy is a type of IGRT involving very detailed imaging and high radiation doses to small volumes. Proton treatment is being used increasingly, with more facilities becoming available worldwide. Proton therapy allows for high-dose radiation to be deposited very accurately at a fixed depth, and is particularly advantageous when the target lies close to critical normal tissue structure, such as in the treatment of the brain stem and in pediatric malignancies [22]. Protons have also been used in the treatment of prostate cancer to achieve dose escalation while minimizing doses to normal tissues [23].

\section{How radiotherapy works}

When radiation interacts with tissue energy, deposition along a track causes ionizations (ejection of an electron from an atom; approximately $10^{5}$ per gray per cell) with a clustering of ionizations at radiation track ends. Ionizations produce free radicals (atoms with unpaired electrons), which are highly reactive and can break chemical bonds. The most harmful effect to cells is damage to DNA, for example, single-strand breaks, double-strand breaks (DSBs) and DNA crosslinks. DSBs are the most important as they are harder to repair than other DNA lesions because the two DNA ends can separate, and accompanying base damage hampers DSB ligation [24]. Unrepaired/ misrepaired DSBs can be lethal/mutagenic. A single unrepaired DSB is lethal if it inactivates a critical gene or triggers apoptosis. Approximately 40 DSBs are induced per gray of sparsely ionizing radiation and most are repaired, with approximately one DSB unrepaired [25]. There are two main pathways for repairing DSBs: nonhomologous end joining (NHEJ) and homologous recombination (HR) [26]. Figure 2 lists many of the genes involved. The two DNA repair pathways are complementary and are used in different situations. HR requires a homologous template, occurs during $\mathrm{S}$ and G2 phase (that is, in proliferating cells) and is error free [27]. Alternative NHEJ pathways operate when the classical route is impeded (for example, due to a gene mutation) and they involve the MRN (MRE11-RAD50-NBN) complex important in HR, PARP1, XRCC1 and LIG1 or LIG3 [27]. The MRN complex also controls sensing, signaling, regulation and responses to DSBs, including ATM activation. ATM phosphorylates Chk2, which targets Cdc25A for degradation, preventing its inhibition of Cdk1-Cyclin $\mathrm{B}$ and Cdk2-Cyclin B, leading to cell cycle arrest. ATM also phosphorylates p53 in response to DSBs. ATR is another protein recruited to DSB sites, and it signals via Chk2 to promote cell cycle arrest. Signaling via ATM/ ATR induces apoptosis or cellular senescence if DSB repair fails. Chromatin structure is also involved and ATM/ATR/DNA-PK cause phosphorylation of the histone H2AX on chromatin alongside DSBs.

Radiation causes other types of damage. Formation of reactive oxygen species (ROS; free radicals involving oxygen) and reactive nitric oxide species (RNOS) induce stress responses, inflammation, and release of cytokines, growth factors and chemokines $[28,29]$. The finding that ATM is also involved in protecting cells from ROS accumulation by stimulating NADPH production and promoting the synthesis of nucleotides for DSB repair [30] highlights the complex interplay between multiple molecular radiation responses.

When radiation interacts with tissues, ionizations produce free radicals that damage DNA. Cells respond by undergoing cell cycle arrest to allow DNA damage repair. 


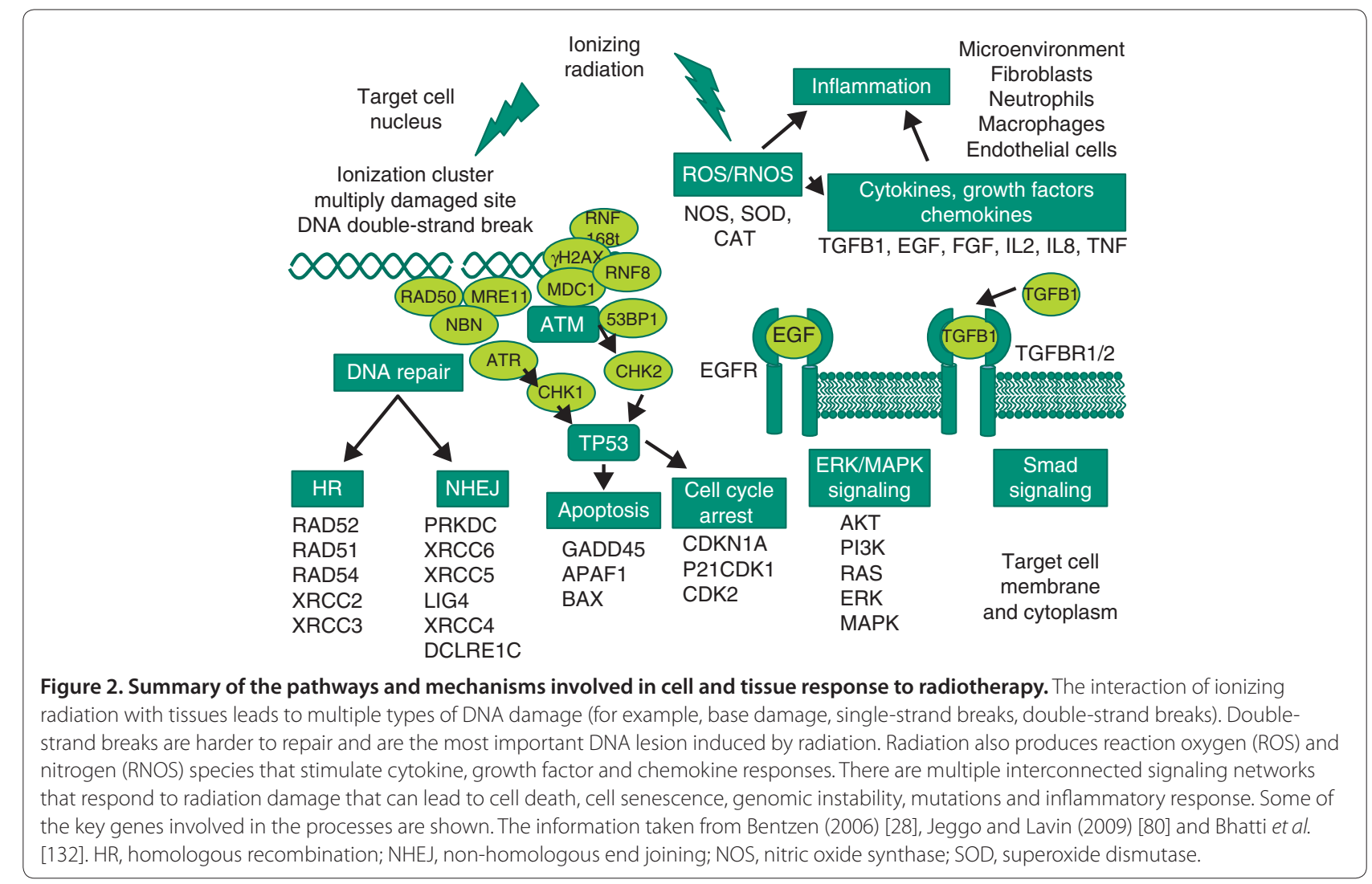

Most damage is repaired, but unrepaired damage causes cell death via necrosis or apoptosis. In general, cells do not die immediately after irradiation - death occurs after replication is attempted often after three or four cell divisions. Proliferating cells are more sensitive than quiescent cells to radiation-induced killing because they have less time to repair damage. Misrepaired DNA damage can cause genomic instability - cells can replicate but damage and cell kill can occur after many cell divisions - and cancer induction after many years. The genome of some people is more unstable than others and individuals with cancer-prone conditions associated with genomic instability, such as ataxia telangiectasia, tend to be radiosensitive. Tumors are more susceptible to the DNA damaging effects of radiation because the cells are generally proliferating faster compared with surrounding normal tissues. Also, because of the many genetic changes that occur in tumors they are generally less able to repair or correctly repair radiation-induced DNA damage. Figure 2 shows many of the important genes involved in cell and tissue response to radiation covering the mechanisms known so far. Until the last decade, DNA damage responses dominated research in the area and understanding the repair pathways continues to be a key area of research. There is increasing interest though in understanding the mechanisms involved in radiation-induced inflammatory and stress responses to ROS and this is also a key area of research. The latter is particularly important for understanding how radiation affects cells not directly irradiated - bystander cell killing [31].

\section{Side effects of radiotherapy}

All patients receiving potentially curative radiotherapy will experience toxicity. There is variation in severity from minor to severe and in duration from weeks to a lifetime. Very rare extreme toxicity results in death and is usually associated with an undiagnosed radiosensitive genetic condition [32]. There are several grading systems for recording radiotherapy side effects, with the common toxicity criteria for adverse events system being used increasingly. Toxicity is not generally documented systematically in routine clinical practice because it is too time consuming [33]. Grading is generally on a scale of none, mild, moderate or severe, with some as either none or yes (for example, sterility following ovary/testes irradiation).

Side effects are typically local occurring in irradiated sites and are numerous, variable and site dependent (Table 1). Acute toxicity occurs during or shortly after completion of treatment and is usually reversible. Acute effects occur in rapidly proliferating tissues as a result of cell death, for example, skin (erythema, dermatitis, 
Table 1. Radiotherapy toxicity

\begin{tabular}{|c|c|c|}
\hline Site/tissue & Acute & Late \\
\hline Skin & $\begin{array}{l}\text { Erythema, dry skin, desquamation, transient hair loss, dermatitis, } \\
\text { pain }\end{array}$ & $\begin{array}{l}\text { Subcutaneous fibrosis (induration/hardening), dry skin (loss } \\
\text { of sweat glands), atrophy (thinning), dyskeratosis, } \\
\text { telangiectasia (blood vessel damage), permanent hair loss, } \\
\text { pigmentation, ulceration (necrosis) }\end{array}$ \\
\hline Central nervous system & $\begin{array}{l}\text { Tiredness, nausea, edema, transient radiation myelitis with } \\
\text { numbness, paresthesia and 'electric-shock'-like sensation often } \\
\text { precipitated by neck flexion (Lhermitte's syndrome) }\end{array}$ & $\begin{array}{l}\text { Fibrosis, demyelination, vascular damage, necrosis, cognitive } \\
\text { decline, hearing loss, hypopituitarism, myelopathy, paralysis }\end{array}$ \\
\hline Head and neck & Erythema, edema, oral mucositis, pain & $\begin{array}{l}\text { Fibrosis, telangiectasia, dry mouth (xerostomia), dental caries, } \\
\text { osteo-radionecrosis, cartilage necrosis }\end{array}$ \\
\hline Eye & Local irritation, watery eyes (increased lacrimation) & $\begin{array}{l}\text { Cataract formation, dry eyes (xerophthalmia), weeping } \\
\text { eye (epiphora) due to impaired lacrimal drainage, } \\
\text { impairment of corneal sensation leading to damage, corneal } \\
\text { ulceration and corneal keratinization, retinal hemorrhage, } \\
\text { exudate and degeneration, optic atrophy }\end{array}$ \\
\hline Lung & Pneumonitis (dyspnea, non-productive cough and chest tightness) & Fibrosis (scarring), dyspnea \\
\hline Breast & Edema & Lymphoedema, fibrosis (hardening), atrophy (shrinking) \\
\hline Intestine & $\begin{array}{l}\text { Mucositis, malabsorption, vomiting, diarrhea, pain, tenesmus, } \\
\text { passage of mucus, bleeding }\end{array}$ & $\begin{array}{l}\text { Malabsorption, adhesions, stenosis, obstruction, proctitis, } \\
\text { fistulae, incontinence, telangiectasia (leading to rectal } \\
\text { bleeding), ulceration }\end{array}$ \\
\hline Kidney, ureter, bladder & $\begin{array}{l}\text { Radiation nephritis, cystitis, increased micturition, dysuria, } \\
\text { hyperemia, mucosal edema }\end{array}$ & $\begin{array}{l}\text { Chronic radiation nephritis (proteinuria, nocturia), } \\
\text { progressive nephropathy with hypertension, and proteinuria, } \\
\text { fibrosis, ulceration, obstruction, incontinence }\end{array}$ \\
\hline Reproductive tract & Vaginal mucositis, cessation of menstruation & $\begin{array}{l}\text { Sterility, induction of menopause, vaginal stenosis, vaginal } \\
\text { obstruction, vaginal dryness, erectile dysfunction }\end{array}$ \\
\hline Bone and cartilage & & $\begin{array}{l}\text { Growth retardation of growing bone, osteoradionecrosis, } \\
\text { cartilage necrosis }\end{array}$ \\
\hline
\end{tabular}

desquamation, hair loss), intestine (diarrhea) and bladder (cystitis). Acute effects are generally manageable (for example, use of feeding tube for patients with head and neck cancer) and transient due to proliferation and repopulation by surviving stem cells. Late effects, manifesting months to years after radiotherapy, can be permanent and are dose limiting. An example is fibrosis, which can lead to obstruction of bowel or urethra following irradiation of tumors in the pelvis, and hardening in the breast following radiotherapy for breast cancer. Severe late toxicity impacts negatively on quality-of-life (for example, bowel incontinence) and can be lifethreatening (for example, bowel obstruction). The long time course for their development prevents titration of dose against toxicity in individual patients, and the relationship between acute and late effects remains unclear [34-36].

The pathogenesis of late toxicity includes fibrosis, atrophy and vascular damage and the molecular processes involved are shown in Figure 2. Fibrosis represents an inflammatory-mediated proliferation response of surviving fibrocytes to growth factors, cytokines and chemokines released following irradiation [28]. Atrophy (tissue shrinkage) reflects cell kill. The effects of fibrosis and atrophy include hardening and shrinkage of an irradiated breast or the development of strictures and malabsorption in irradiated small bowel. Vascular damage can cause small vessel dilation, manifesting as telangiectasia in the skin or hematuria (blood cells in urine due to bleeding) in an irradiated bladder. Alternatively, vascular damage can cause small vessel constriction, which manifests as ischemia and necrosis, and examples include bowel perforation and fistulae. Other important late effects include hormone deficiencies, infertility and, in patients with a long life expectancy, second malignancies.

A challenge for radiogenetic/radiogenomic studies is to obtain cohorts of patients with good quality (that is, complete, longitudinal, including pre-treatment, and comprehensive) toxicity data along with other data on possible non-genetic risk factors (Table 2). Several factors influence the likelihood of a patient developing toxicity; these factors are broadly related to physics (for example, toxicity increases with increasing radiation dose and volume), concurrent treatments (for example, chemotherapy tends to increase toxicity), patient history (for example, patients with comorbidities such as diabetes and rheumatoid arthritis tend to suffer more toxicity, smoking increases toxicity) and genetics. The challenge 
Table 2. Information for radiogenetic/radiogenomic studies

\begin{tabular}{ll}
\hline Category & Information \\
\hline Tumor & Type, stage (tumor, node, metastases (TNM)), pathology, volume \\
Patient & $\begin{array}{l}\text { Age, smoking history, alcohol use, ethnicity, weight, height, breast volume for breast patients (cup size), co-morbidity (for example, diabetes, } \\
\text { collagen vascular disease, hypertension, inflammatory bowel disease) }\end{array}$ \\
Treatment & $\begin{array}{l}\text { Total dose, number of fractions, dose per fraction, overall treatment time, use of chemotherapy, use of hormone therapy, use of surgery and } \\
\text { postoperative complications, concurrent medications (for example, statins) }\end{array}$ \\
Physics & Total radiation dose, dose per fraction, overall treatment time, planned doses to critical normal tissues \\
Toxicity & Pre-treatment data and collection a minimum at end of treatment, 6 months and then yearly. Use of site-specific patient-reported toxicity \\
& preferable as primary endpoints as physician-reported toxicity underestimates toxicity. Physician-reported toxicity
\end{tabular}

for radiogenetics/radiogenomics is to quantify accurately the non-genetic risk factors so that the influence of genetics can be detected reliably.

\section{Genetics of radiosensitivity}

Radiosensitivity is a broad term applied to cells, tissues and individuals. Different cell types vary in radiosensitivity as do cells from different individuals. Some tissues are more tolerant of radiation because of their organization - if a small part of a lung is destroyed by a high dose of radiation, lung function can be maintained by remaining healthy tissue, but if a small section of spinal cord is damaged it can lead to paralysis. Some tissues are sensitive because they have a higher level of proliferation or undergo apoptosis. Individuals also vary in radiosensitivity and this can be associated with cellular radiosensitivity and/or genomic instability.

\section{Measuring radiosensitivity}

Radiosensitivity is typically measured in research studies (not routine clinical practice) using cells (mainly blood lymphocytes or fibroblasts cultured from skin samples). Cells are irradiated and can be assayed using several approaches (Figure 3). The gold standard is a clonogenic assay, which is a sensitive method for measuring radiosensitivity over several logs of cell kill. Clonogenic assays assess reproductive integrity, that is, ability of single cells to form a colony with a minimum of 50 cells (representing at least five to six cell divisions) [37]. Other assays are used to assess radiosensitivity: chromosome damage endpoints, DNA damage endpoints, apoptosis [38,39] and cell cycle delay [40]. Examples of chromosome damage endpoints are G2 [41] and micronucleus [42] assays (Figure 3). An example of a DNA damage assay involves scoring radiation-induced gammaH2AX foci [43]. Measurements of radiosensitivity in humans show the heritability of the trait (Table 3) and an approximate normal distribution (like other polygenic traits such as height) $[41,44]$ (Figure 3). Current understanding is that radiosensitivity is an inherited polygenic trait, dependent on the interaction of many genes/gene products involved in multiple cell processes [45].

\section{Which genes are important?}

Study of genetic syndromes associated with mutations in genes in DNA repair pathways provided the first insight into human variations in radiosensitivity. Ataxia telangiectasia, associated with mutations in ATM, was the first reported syndrome with extreme clinical (life-threatening radiotherapy toxicity) and cellular radiosensitivity [46]. Other syndromes have been identified associated with mutations in genes involved in DNA recognition and repair, cellular radiosensitivity, genomic instability and cancer pre-disposition (Table 4). As NHEJ is involved in VDJ recombination (DNA rejoining process during $T$ and $\mathrm{B}$ cell development), syndromes involving defective NHEJ genes are also associated with immunodeficiency. Several syndromes are associated with genomic instability and a high risk of radiation-induced cancers, for example, Li-Fraumeni (TP53) and retinoblastoma (RB1) [47], but cellular and clinical radiosensitivity are not generally seen [44]. Other evidence comes from experimental data showing mutations in genes involved in DNA repair pathways increase cellular radiosensitivity, for example, the radiosensitive Chinese hamster ovary cell lines (gene mutated): irs1 (XRCC2), irs2 (XRCC8), irs3 (RAD51C), irs20 (PRKDC), IRS1-SF (XRCC3), xrs5 (XRCC5) and XR-1 (XRCC4) [48].

Other genes of interest are downstream effectors of cellular responses to radiation-induced damage, such as those involved in the control of apoptosis and cell cycling (Figure 2). Cells able to undergo apoptosis or having impaired cell cycle arrest following irradiation tend to be radiosensitive [49-51]. As ROS/RNOS are important (Figure 2), genes encoding antioxidants involved in freeradical scavenging are also implicated, for example, superoxide dismutase (SOD1), glutathione $S$-transferases (for example, GSTA5) and catalase (CAT), and germline genetic variations that predispose to increased levels of ROS may predispose to increased radiation toxicity [52]. ROS/RNOS pathways are less widely studied than those involving DNA repair in terms of cellular and clinical radiosensitivity, but there is evidence that changing levels of antioxidants can alter cellular radiosensitivity [53,54]. Cytokines such as transforming growth factor beta 


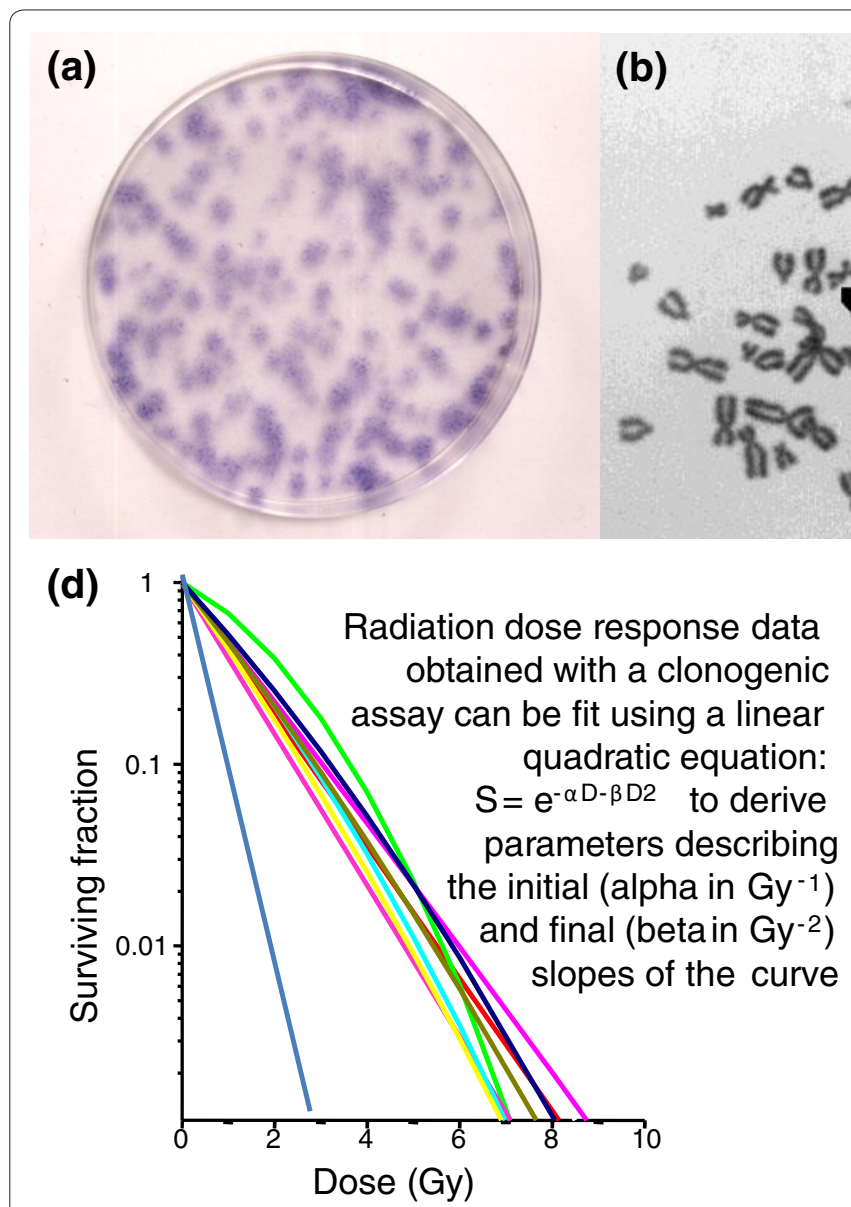

(e)

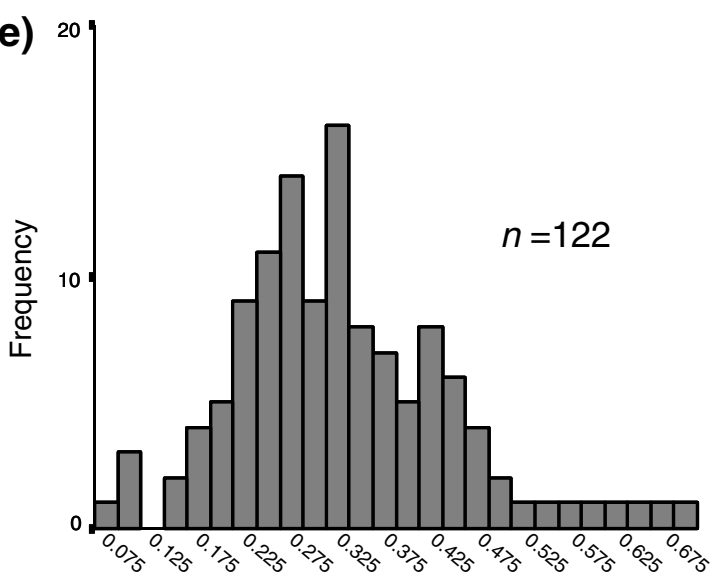

Figure 3. Measuring radiosensitivity. There are many assays for measuring radiosensitivity. The gold standard is a clonogenic assay where single cells are plated and allowed to grow for 1 to 4 weeks to assess ability to form colonies. (a) Colonies from fibroblasts cultured from a human skin sample. As it takes several weeks to culture fibroblasts and carry out a clonogenic assay, more rapid assays are often used. (b) An example of a more rapid assay is the $\mathrm{G} 2$ assay: a peripheral blood sample is taken, lymphocytes are stimulated to proliferate with the mitogen phytohemagglutinin, after 72 hours the cells are irradiated with 0.5 gray (Gy), and after 30 minutes colcemid is added for 60 minutes to arrest cells at metaphase that were in G2 when irradiated. The number of chromosome aberrations (arrows) is scored relative to unirradiated controls [41]. (c) Another example is the micronucleus assay: peripheral blood lymphocytes are irradiated with approximately 2 Gy and incubated for 2 days, cytochalasin B is added to prevent cytoplasm division after mitosis, and cells are harvested after 1 day and the number of micronuclei per 100 to 1,000 cells is scored [42]. Demonstration of cellular radiosensitivity in individuals with life-threatening radiotherapy toxicity or cancer-predisposing syndromes usually involves fibroblasts and derivation of radiation survival curves. (d) Survival curves for a number of individuals, including one (blue line) with ataxia telangiectasia, showing extreme cellular radiosensitivity. Parameters can be obtained from fitting curves to the data and parameters that reflect the initial slope, such as alpha and surviving fraction at 2 (SF2) or 3 Gy, are better at showing differences in radiosensitivity between people [133]. (e) Normal (that is, non-syndromic) individuals vary in radiosensitivity with a distribution that is approximately normal [134].

(TGFB1), tumor necrosis factor alpha (TNF), interferons and interleukins are also involved in the development of toxicity. For example, IL17 receptor knockout mice have enhanced myelotoxicity and impaired hemopoietic recovery following irradiation [55]. There is now substantial evidence for the importance of TGFB1 in the pathogenesis of fibrosis following radiotherapy $[28,56]$. In comparison with DNA repair defects, however, there is less evidence for a direct role in clinical and cellular radiosensitivity but the area has been less widely studied. Irradiated homozygous TGFB1 knockout fibroblasts were more radiosensitive than wild-type fibroblasts [57].
However, patients with Marfan syndrome associated with mutations in FBN (fibrillin-1; increases interstitial fibrosis and TGFB1 activation in murine knockouts) undergoing radiotherapy showed no increased toxicity [58]. It is an area requiring further study.

\section{Genetic variation and radiotherapy toxicity}

Numerous studies have reported associations between genetic variation reported as SNPs in the candidate genes described above and radiotherapy toxicity (Table 5). However, most studies have involved only small patient numbers and no replication. The only replication study 
Table 3. Evidence for heritability of radiosensitivity as a human trait

\begin{tabular}{|c|c|c|c|}
\hline Study population & Assay* & Heritability (\%) & Reference \\
\hline $\begin{array}{l}16 \text { Radiosensitive breast cancer survivors and } 37 \text { first-degree relatives, } \\
4 \text { breast cancer survivors with normal radiosensitivity and } 15 \text { first-degree relative }\end{array}$ & G2 & 82 & [41] \\
\hline 23 Cancer survivors, 29 partners, 38 offspring, 27 controls & G2 & 67 & [76] \\
\hline 148 Monozygotic and 57 dizygotic twin pairs; 50 siblings & Apoptosis & 63 & [77] \\
\hline 199 Father, mother, offspring trios & Apoptosis & 61 & [78] \\
\hline 38 Dizygotic and 16 monozygotic twin pairs & Apoptosis; cell cycle delay & $68 ; 59$ & [40] \\
\hline 29 Cancer survivors, 29 partners, 53 offspring & G2 & 58 to 78 & [79] \\
\hline 39 Monozygotic and 10 dizygotic twin pairs & $\mathrm{MN}$ & 68 & [42] \\
\hline
\end{tabular}

*Peripheral blood lymphocytes were used in all studies. The G2 assay involves scoring chromosome damage in cells irradiated in G2 phase of the cell cycle. The micronucleus (MN) assay involves irradiating cells and preventing progression through mitosis. Radiation-damaged chromosomes form micronuclei that are counted.

carried out failed to validate previous findings [59]. The lack of independent validation for any of the SNPs studied makes it impossible to say with certainty whether any predispose a patient to suffer toxicity. Due to the generally small numbers studied and overestimation of risks associated with rare alleles, the studies have lacked the statistical robustness required for changing patient management $[45,60]$.

\section{First genome-wide association studies}

With the rapid reduction in cost of genotyping, there is increasing interest in carrying out GWASs to identify new genes associated with toxicity. Kerns et al. [3] recently reported the results of the first GWAS. In a study of African-American patients with prostate cancer, 27 who developed erectile dysfunction after radiotherapy were compared with 52 controls. The SNP rs2268363 in the follicle-stimulating hormone receptor gene (FSHR; involved in testes development and spermatogenesis) was associated with erectile dysfunction with a $P$-value that reached genome-wide significance $\left(P=5.5 \times 10^{-8}\right)$ and an odds ratio of 7.0 (95\% confidence interval 3.4 to 12.7 ). Of course, we cannot state with certainty that the FSHR SNP is associated with radiotherapy toxicity until the finding is validated. Unfortunately many highly significant phenotype-genotype associations are found in GWASs but few are replicated because of a high level of false positives due to studying several hundred thousand SNPs, population stratification and genotyping artifacts [61]. SNPs with rare minor allele frequencies and poor genotype call rates are unlikely to replicate [61]. With the caveat that the findings require validation, the study of Kerns et al. represents an important first step for the radiotherapy community and it is interesting that the SNP possibly identified is tissue specific.

Another recent study carried out a genome-wide screen of microsatellite markers in 360 patients with a variety of cancers and identified a marker in the promoter region of SEM3A (required for neuronal development) associated with acute radiotherapy toxicity [62]. Again, there has been no confirmatory study but, as the gene had no previous known role in modulating radiosensitivity, the authors showed that siRNA knockdown increased fibroblast radioresistance [62].

A third GWAS looked at 277 lymphoblastoid lines to identify SNPs associated with radiosensitivity measured in vitro. The work employed pharmacogenetic methods measuring viability after graded radiation doses (up to $45 \mathrm{~Gy}$ ) and analyzed area under dose response curves to measure radiosensitivity, none of which is a standard radiobiology approach. The following genes were identified and suggested to influence radiosensitivity using siRNA (in tumor cell lines): C13orf34, MAD2lI, PLK4, TPD52 and DEPDC1B [63].

The three GWASs described above all have their limitations; it remains to be seen whether the findings are validated and no firm conclusions can be drawn. However, they represent important first steps towards identifying genotypes associated with radiosensitivity/radiotherapy toxicity and in collecting the samples and data required that should eventually contribute to international pooled replication studies as other GWASs emerge in the next few years. It is interesting that the genes possibly identified in the three studies are not obvious radiationassociated candidate genes; this is consistent with current opinion that we have insufficient understanding of the molecular pathogenesis of radiotherapy toxicity as a polygenic phenotype. Information from GWASs of other phenotypes suggest the allelic architecture underlying radiosensitivity will include a spectrum ranging from rare, highly penetrant to low-risk common alterations [60]. Although GWASs are currently only expected to capture a fraction of the genetic determinants because several hundreds of thousands of patients must be studied to identify variants with small effects, it is important that the radiotherapy research community work together to pick this 'low hanging fruit'. Such work is vital to ensure we have the samples and data to exploit new 
Table 4. Genes involved in human radiosensitivity identified from syndromes

\begin{tabular}{|c|c|c|}
\hline Gene & Characteristics & References \\
\hline ATM & $\begin{array}{l}\text { Mutated in individuals with AT; chromosomal instability, immunodeficiency, cancer predisposition, extreme clinical and } \\
\text { cellular radiosensitivity; central component of signaling responses to DNA damage }\end{array}$ & {$[46,80]$} \\
\hline MRE11 & $\begin{array}{l}\text { Mutated in individuals with AT-like disorder; immunodeficiency, cellular radiosensitivity; part of MRN complex involved in DNA } \\
\text { damage detection and initiation of response }\end{array}$ & [81] \\
\hline LIG4 & $\begin{array}{l}\text { Mutated in individuals with LIG4-syndrome; chromosomal instability; immunodeficiency, clinical and cellular radiosensitivity; } \\
\text { part of NHEJ pathway }\end{array}$ & [82] \\
\hline NBN & $\begin{array}{l}\text { Mutated in individuals with Nijmegen breakage syndrome; chromosomal instability; immunodeficiency; clinical and cellular } \\
\text { radiosensitivity; cancer predisposition; part of MRN complex involved in DNA damage detection and initiation of response }\end{array}$ & [83] \\
\hline RAD50 & $\begin{array}{l}\text { Mutated in individual with Nijmegen breakage syndrome-like disorder; chromosomal instability; no immunodeficiency, cellular } \\
\text { radiosensitivity; part of MRN complex }\end{array}$ & {$[84]$} \\
\hline RNF168 & Mutated in individuals with RIDDLE syndrome; cellular radiosensitivity; immunodeficiency; recruitment of 53BP1 to sites of DSBs & {$[85]$} \\
\hline $\begin{array}{l}\text { DCLREIC } \\
\text { involved in } N\end{array}$ & $\begin{array}{l}\text { Encodes artemis; mutated in individuals with radiosensitive severe combined immunodeficiency (RS-SCID); cellular radiosensitivity; } \\
\text { IHEJ }\end{array}$ & [82] \\
\hline PRKDC & Encodes DNA-PKcs; DNA-PK-RS-SCID syndrome; immunodefiency; cellular radiosensitivity; involved in NHEJ & [43] \\
\hline $\begin{array}{l}\text { SMCL1A } \\
\text { and SMC3 }\end{array}$ & $\begin{array}{l}\text { Mutated in individuals with Cornelia de Lange syndrome; chromosomal instability; cellular radiosensitivity during G2 phase; sister } \\
\text { chromatid cohesion }\end{array}$ & [86] \\
\hline
\end{tabular}

AT, ataxia telangiectasia; NHEJ, non-homologous end joining.

research strategies being developed to identify rare variants, for example, including populations with different ethnicity/founder populations where variants are more prevalent and studying structural variation (for example, copy number variants) [64].

In 2011, the results were published of the first GWAS looking at radiotherapy-induced second cancers [4]. The study involved individuals who underwent radiotherapy for Hodgkin's lymphoma as children: 100 cases and 89 cancer-free controls in a discovery cohort and 96 cases and 82 controls in a replication cohort. Two variants at chromosome 6q21 were identified implicating PRDM1 (also referred to as BLIMP1). PRDM1 encodes a transcription factor that acts as a repressor of beta-interferon gene expression to co-ordinate response to viral infection by regulating proliferation and differentiation. There are a number of interesting observations to make from the study. First, the implication that altered immune function increases the risk of radiation-induced cancers. Second, the effect sizes associated with the SNPs identified were higher than expected from observations emerging for other traits (per allele odds ratios of 2 to 4) [65]. Third, although relatively few individuals were studied (compared with other GWASs) the findings were not only replicated but also confirmed in a functional assay. The high effect size was attributed to a strong genetic susceptibility with young age of radiotherapy as the contribution of genetics to cancer susceptibility is likely to decrease with age as environmental and lifestyle factors exert an increasing influence [65], which is also a likely explanation for the ability to use a small sample size.

The increasing recognition that most GWASs must include thousands of patients $[45,60]$ led to the establishment of a radiogenomics consortium in 2009 [66]. The consortium created an important link between existing collaborative groups [67-69] and other smaller consortia. The consortium should provide a route for sharing and developing expertise and quality assurance procedures, developing best practices for data collection, and pooling data and carrying out replication studies. There are many challenges in radiogenomics: (1) radiotherapy schedules vary between centers and countries; (2) recording radiotherapy toxicity is not routine and there are multiple scoring schemes; (3) there are multiple sites (for example, breast, head and neck, prostate) and multiple endpoints involved within each site (Table 1); (4) there is no consensus on the best toxicity time point to use (acute, 2 or more years); (5) there is no standardization of possible non-genetic risk factor data collection (Table 2); (6) more work is required to improve our ability to incorporate radiation physics data (the actual dose received by surrounding normal tissues); (7) we need to determine the best way of pooling data from multiple studies. A key advance in the area will be the standardization of data collection and further GWASs involving large cohorts.

\section{Predicting response to radiotherapy}

Studies measuring radiosensitivity to predict radiotherapy toxicity have used a variety of assays, yielded mixed results and there is currently no method suitable for routine clinical use that accurately assesses the radiosensitivity of an individual [70]. There has been little standardization of the methods used and the approaches are varied in terms of samples (for example, blood, skin, plasma), timing (for example, before, during) assays (for example, clonogenic, DNA damage, chromosome damage, level of apoptosis assessed using flow cytometry, cytokine production assessed using ELISA, gene expression profiling, 
Table 5. SNPs and risk of radiotherapy toxicity

\begin{tabular}{|c|c|c|c|c|}
\hline Gene(s) investigated & Cancer & Number & Association(s) & Reference \\
\hline 21 & Esophageal & 81 & XRCC2, GSTP1 & [87] \\
\hline TP53 & Lung & 253 & Yes & [88] \\
\hline$X R C C 1$ & Prostate & 603 & Yes & [89] \\
\hline XRCC1, XRCC3, XPD, GSTM1, GSTT1, MSH2, MLH1, MSH3, MGMT & Breast & 87 & $X R C C 1, X R C C 3, M S H 2$ & [90] \\
\hline 59 & NSCLC & 173 & PTGS22, IL1A, IL8, TNF, MIF, NOS3 & [91] \\
\hline XRCC1, OGG1, MRCC3 & Breast & 43 & No & [92] \\
\hline$T G F B 1, X R C C 1, X R C C 2$ & Head and neck & 60 & $T G F B 1, X R C C 1$, No. risk alleles & [93] \\
\hline$X R C C 1$ & Breast & 119 & Yes & [94] \\
\hline ATM & Lung & 253 & Yes & [95] \\
\hline ATM, GSTP1, SOD2, XPD, XRCC1 & Breast & 69 & No. risk alleles & [96] \\
\hline 211 & Cervix & 243 & NPAT-ATM, AURKA & [97] \\
\hline TGFB1, L10P, C509T, G915C & Breast & 190 & No & [98] \\
\hline TGFB1 & Breast & 778 & No & [99] \\
\hline MCIR & Mixed & 30 & Yes & [100] \\
\hline APEX1, XRCC1, XRCC2, XRCC3,XPD, TP53, P21 & Breast & 409 & TP53 & [101] \\
\hline TGFB1 & NSCLC & 164 & Yes & [102] \\
\hline XRCC3, RAD51, XRCC5, LIG4, XRCC6 & Head and neck & 88 & $\mathrm{XRCC} 3, \mathrm{XRCC6}$ & [103] \\
\hline $\begin{array}{l}\text { XRCC1, APEX1, OGG1, XRCC2, XRCC3, NBN, XPA, ERCC1, XPC, } \\
\text { TP53, P21, MDM2 }\end{array}$ & Prostate & 405 & No & [104] \\
\hline TGFB1 & Prostate & 445 & No & [105] \\
\hline GSTA1, GSTM1, GSTT1, GSTP1, MPO, SOD2, NOS3, CAT & Breast & 390 & GSTA1, NOS3 & [52] \\
\hline VEGF & Prostate & 99 & Yes & [106] \\
\hline TGFB1 & Prostate & 141 & Yes & [107] \\
\hline 3,144 SNPs in 494 genes & Breast & 156 & Associations & [108] \\
\hline SOD2, XRCC1, XRCC3 & Prostate & 135 & $X R C C 1, S O D 2, S O D 2+X R C C 3$ & [109] \\
\hline ATM, SOD2, XRCC1, XRCC3, TGFB1, RAD21 & Mixed severe reactors & 30 & No. risk alleles & [39] \\
\hline TP53, CDKN1A & Breast & 22 & No & [110] \\
\hline 450 SNPs in 115 genes & Prostate & 197 & SART1, ID3, EPDRI, PAH, XRCC6 & [111] \\
\hline 999 SNPs in 137 genes & Breast & 399 & CD44, MAD2L2, PTTG1, RAD9A, LIG3 & [69] \\
\hline TGFB1, XRCC1, APE1, DHFR, CX3CR1, MTHFR, EPHX1 & Breast & 167 & XRCC1, TGFB1 & [112] \\
\hline ATM & Breast & 252 & Yes & [113] \\
\hline GSTM1, GSTP1, GSTT1 & Breast & 253 & GSTP1 & [114] \\
\hline CAT, SOD2, MPO, NOS3 & Breast & 446 & No & [115] \\
\hline$X R C C 1$ & Breast & 247 & Yes & [116] \\
\hline TP53, p21 & Breast & 446 & No & [117] \\
\hline$X R C C 3, X R C C 2, N B S 1$ & Breast & 446 & No & [118] \\
\hline TGFB1 & Gynae & 78 & No & [119] \\
\hline 49 & Prostate & 83 & LIG4, ERCC2, CYP2D6 & [120] \\
\hline TGFB1, SOD2, XRCC1, XRCC3, APEX, ATM & Breast & 120 & No & [59] \\
\hline GSTA1, GSTP1, GSTM1, GSTT1 & Breast & 446 & GSTP1 & [121] \\
\hline ERCC4 & Head and neck & 130 & Yes & [122] \\
\hline$X R C C 1, A P E 1, X P D$ & Breast & 446 & XRCC1, APE1 & [123] \\
\hline TGFB1, SOD2, XRCC1, XRCC3, APEX, ATM & Breast & 52 & TGFB1 & [124] \\
\hline$X R C C 1, X R C C 3, O G G 1$ & Gynae & 62 & No. risk alleles & [125] \\
\hline$X R C C 1$ & Breast & 254 & Yes & [126] \\
\hline TGFB1 & Breast & 103 & Yes & [127] \\
\hline TGFB1, SOD2, XRCC1, XRCC3, APEX & Breast & 41 & No. risk alleles & [128] \\
\hline ATM & Breast & 254 & Yes & [129] \\
\hline SOD2 & Breast & 80 & No & [130] \\
\hline RAD21 & Mixed & 19 & Yes & [131] \\
\hline
\end{tabular}

Gynae, cervix and endometrial cancer; No. risk alleles, number of homozygous rare and heterozygous alleles for the various SNPs studied; NSCLC, non-small cell lung cancer, SNP, single nucleotide polymorphism. 
proteomics, metabolomics). A long-term goal of the research area is to develop a test that predicts the likelihood of a patient suffering side effects [45]. Theoretical studies have shown that such a test should improve the therapeutic ratio of radiotherapy by allowing dose escalation in radioresistant patients [45]. Predictive clinical models are being developed [71,72]. These cancer type-specific or endpoint-specific models integrate clinical (for example, diabetes, age, smoking, hormonal therapy) and dosimetric (mean doses to critical normal tissues) to obtain an estimate of the probability of developing toxicity. The models can easily be extended to incorporate genotyping data. An example comes from Kerns et al. [3], where four SNPs identified in their GWAS were better at predicting erectile dysfunction than a combination of clinical factors (age, stage, radiation dose, hormone use, diabetes, smoking). However, the finding should be interpreted with caution, as predictive value is generally overestimated when the model is created and evaluated in the same study population, particularly if the same data were first used to select the strongest genetic predictors out of a large set of genotyped variants [73].

\section{Conclusions}

GWASs are increasing understanding of the genetic variation underlying common traits and diseases and, in pharmacogenomics, are starting to identify genetic determinants of drug efficacy and adverse effects [74,75]. Radiogenomics is an emerging and developing research area, and it faces many challenges surrounding the collection of sufficiently large cohorts with detailed recording of toxicity and information on non-genetic risk factors, which are not generally collected routinely. The GWASs of Kerns et al. [3] and Best et al. [4] are important because they are the first radiogenomics studies published, but the field will only advance with international data-sharing and methodology-sharing co-operation. The establishment of a Radiogenomics Consortium should provide a route for addressing the need for standardizing data collection, pooling data and replication studies.

\section{Abbreviations}

CT, computed tomography; DSB, double-strand break; EBRT, external beam radiotherapy; GWAS, genome-wide association study; $H R$, homologous recombination; IGRT, image guided radiotherapy; IL, interleukin; IMRT, intensity modulated radiotherapy; NHEJ, non-homologous end joining; RNOS, reactive nitrogen species; ROS, reactive oxygen species; siRNA, small interfering RNA; SNP, single nucleotide polymorphism.

\section{Competing interests}

The authors declare that they have no competing interests.

\section{Authors' contributions}

CMW and GB contributed to the drafting of the manuscript. CMW carried out revisions and gave final approval of this version to be published.

\section{Acknowledgements}

The authors would like to thank Drs Susan Davidson and Charlotte Coles for images in Figure 1. The authors' work is supported by Cancer Research UK.
Dr Gillian Barnett is also funded by the Royal College of Radiologists and has received funding from Addenbrooke's Charitable Trust.

\section{Author details}

'School of Cancer and Enabling Sciences, The University of Manchester, Manchester Academic Health Science Centre, The Christie, Wilmslow Road, Manchester M20 4BX, UK. 'University of Cambridge Department of Oncology, Cambridge University Hospitals NHS Foundation Trust, Cambridge CB2 0QQ, UK.

Published: 23 August 2011

\section{References}

1. Bentzen SM, Constine LS, Deasy JO, Eisbruch A, Jackson A, Marks LB, Ten Haken RK, Yorke ED: Quantitative Analyses of Normal Tissue Effects in the Clinic (QUANTEC): an introduction to the scientific issues. Int J Radiat Oncol Biol Phys 2010, 76:S3-9.

2. Emami B, Lyman J, Brown A, Coia L, Goitein M, Munzenrider JE, Shank B, Solin $L J$, Wesson M: Tolerance of normal tissue to therapeutic irradiation. Int J Radiat Oncol Biol Phys 1991, 21:109-122.

3. Kerns SL, Ostrer H, Stock R, Li W, Moore J, Pearlman A, Campbell C, Shao Y, Stone N, Kusnetz L, Rosenstein BS: Genome-wide association study to identify single nucleotide polymorphisms (SNPs) associated with the development of erectile dysfunction in African-American men after radiotherapy for prostate cancer. Int J Radiat Oncol Biol Phys 2010, 78:1292-1300

4. Best T, Li D, Skol AD, KirchhoffT, Jackson SA, Yasui Y, Bhatia S, Strong LC, Domchek SM, Nathanson KL, Olopade OI, Huang RS, Mack TM, Conti DV, Offit K, Cozen W, Robison LL, Onel K.: Variants at 6q21 implicate PRDM1 in the etiology of therapy-induced second malignancies after Hodgkin's lymphoma. Nat Med 2011, 17:941-943.

5. Delaney G, Jacob S, Featherstone C, Barton M: The role of radiotherapy in cancer treatment: estimating optimal utilization from a review of evidence-based clinical guidelines. Cancer 2005, 104:1129-1137.

6. Bentzen SM, Heeren G, Cottier B, Slotman B, Glimelius B, Lievens Y, van den Bogaert W: Towards evidence-based guidelines for radiotherapy infrastructure and staffing needs in Europe: the ESTRO QUARTS project. Radiother Oncol 2005, 75:355-365.

7. Sacks W, Fung CH, Chang JT, Waxman A, Braunstein GD: The effectiveness of radioactive iodine for treatment of low-risk thyroid cancer: a systematic analysis of the peer-reviewed literature from 1966 to April 2008. Thyroid 2010, 20:1235-1245.

8. Ahmed S, Winter JN, Gordon LI, Evens AM: Radioimmunotherapy for the treatment of non-Hodgkin lymphoma: current status and future applications. Leuk Lymphoma 2010, 51:1163-1177.

9. Mayles WP: Survey of the availability and use of advanced radiotherapy technology in the UK. Clin Oncol 2010, 22:636-642.

10. Glatstein E: Intensity-modulated radiation therapy: the inverse, the converse, and the perverse. Semin Radiat Oncol 2002, 12:272-281.

11. Hong TS, Ritter MA, Tome WA, Harari PM: Intensity-modulated radiation therapy: emerging cancer treatment technology. Br J Cancer 2005 , 92:1819-1824

12. Moran JM, Elshaikh MA, Lawrence TS: Radiotherapy: what can be achieved by technical improvements in dose delivery? Lancet Onco/ 2005, 6:51-58.

13. Ten Haken RK, Lawrence TS: The clinical application of intensity-modulated radiation therapy. Semin Radiat Oncol 2006, 16:224-231.

14. Veldeman L, Madani I, Hulstaert F, De Meerleer G, Mareel M, De Neve W: Evidence behind use of intensity-modulated radiotherapy: a systematic review of comparative clinical studies. Lancet Onco/ 2008, 9:367-375.

15. Pow EH, Kwong DL, McMillan AS, Wong MC, Sham JS, Leung LH, Leung WK: Xerostomia and quality of life after intensity-modulated radiotherapy vs. conventional radiotherapy for early-stage nasopharyngeal carcinoma: initial report on a randomized controlled clinical trial. Int J Radiat Oncol Biol Phys 2006, 66:981-991.

16. Nutting CM, Morden JP, Harrington KJ, Urbano TG, Bhide SA, Clark C, Miles EA, Miah AB, Newbold K, Tanay M, Adab F, Jefferies SJ, Scrase C, Yap BK, A'Hern RP, Sydenham MA, Emson M, Hall E; PARSPORT trial management group: Parotidsparing intensity modulated versus conventional radiotherapy in head and neck cancer (PARSPORT): a phase 3 multicentre randomised controlled trial. Lancet Oncol 2011, 12:127-136.

17. Barnett GC, Wilkinson JS, Moody AM, Wilson CB, Twyman N, Wishart GC, 
Burnet NG, Coles CE: Randomized controlled trial of forward-planned intensity-modulated radiotherapy for early breast cancer: interim results at 2 years. Int J Radiat Oncol Biol Phys 2011, in press.

18. Donovan E, Bleakley N, Denholm E, Evans P, Gothard L, Hanson J, Peckitt C, Reise S, Ross G, Sharp G, Symonds-Tayler R, Tait D, Yarnold J: Breast Technology Group: Randomised trial of standard 2D radiotherapy (RT) versus intensity modulated radiotherapy (IMRT) in patients prescribed breast radiotherapy. Radiother Oncol 2007, 82:254-264.

19. Dawson LA, Sharpe MB: Image-guided radiotherapy: rationale, benefits, and limitations. Lancet Oncol 2006, 7:848-858.

20. van Herk M: Different styles of image-guided radiotherapy. Semin Radiat Oncol 2007, 17:258-267.

21. Verellen D, De Ridder M, Linthout N, Tournel K, Soete G, Storme G: Innovations in image-guided radiotherapy. Nat Rev Cancer 2007, 7:949-960.

22. Ares C, Khan S, Macartain AM, Heuberger J, Goitein G, Gruber G, Lutters G, Hug EB, Bodis S, Lomax AJ: Postoperative proton radiotherapy for localized and locoregional breast cancer: potential for clinically relevant improvements? Int J Radiat Oncol Biol Phys 2009, 76:685-697.

23. Nguyen PL, Trofimov A, Zietman AL: Proton-beam vs intensity-modulated radiation therapy. Which is best for treating prostate cancer? Oncology 2008, 22:748-754; discussion 754, 757

24. O'Driscoll M, Jeggo PA: The role of double-strand break repair - insights from human genetics. Nat Rev Cancer 2006, 7:45-54.

25. Martin LM, Marples B, Coffey M, Lawler M, Lynch TH, Hollywood D, Marignol L: DNA mismatch repair and the DNA damage response to ionizing radiation: making sense of apparently conflicting data. Cancer Treat Rev 2010, 36:518-527.

26. Jackson SP: Sensing and repairing DNA double-strand breaks. Carcinogenesis 2002, 23:687-696.

27. Polo SE, Jackson SP: Dynamics of DNA damage response proteins at DNA breaks: a focus on protein modifications. Genes Dev 2011, 25:409-433.

28. Bentzen SM: Preventing or reducing late side effects of radiation therapy: radiobiology meets molecular pathology. Nat Rev Cancer 2006, 6:702-713.

29. Zhao W, Diz Dl, Robbins ME: Oxidative damage pathways in relation to normal tissue injury. Br J Radiol 2007, 80(Spec No. 1):S23-S31.

30. Cosentino C, Grieco D, Costanzo V: ATM activates the pentose phosphate pathway promoting anti-oxidant defence and DNA repair. EMBO J 2011, 30:546-555.

31. Prise KM, O'Sullivan JM: Radiation-induced bystander signalling in cancer therapy. Nat Rev Cancer 2009, 9:351-360.

32. Riballo E, Critchlow SE, Teo SH, Doherty AJ, Priestley A, Broughton B, Kysela B, Beamish H, Plowman N, Arlett CF, Lehmann AR, Jackson SP, Jeggo PA: Identification of a defect in DNA ligase IV in a radiosensitive leukaemia patient. Curr Biol 1999, 9:699-702.

33. Bentzen SM, Dorr W, Anscher MS, Denham JW, Hauer-Jensen M, Marks LB, Williams J: Normal tissue effects: reporting and analysis. Semin Radiat Oncol 2003, 13:189-202.

34. Burnet NG, Wurm R, Nyman J, Peacock JH: Normal tissue radiosensitivity - how important is it? Clin Oncol (R Coll Radiol) 1996, 8:25-34

35. Bentzen SM, Overgaard M: Relationship between early and late normaltissue injury after postmastectomy radiotherapy. Radiother Oncol 1991, 20:159-165

36. Bentzen SM, Overgaard M, Overgaard J: Clinical correlations between late normal tissue endpoints after radiotherapy: implications for predictive assays of radiosensitivity. Eur J Cancer 1993, 29A:1373-1376.

37. Puck TT, Marcus PI: Action of $x$-rays on mammalian cells. J Exp Med 1956, 103:653-666.

38. Azria D, Ozsahin M, Kramar A, Peters S, Atencio DP, Crompton NE, Mornex F, Pelegrin A, Dubois JB, Mirimanoff RO, Rosenstein BS: Single nucleotide polymorphisms, apoptosis, and the development of severe late adverse effects after radiotherapy. Clin Cancer Res 2008, 14:6284-6288.

39. Ozsahin M, Crompton NE, Gourgou S, Kramar A, Li L, Shi Y, Sozzi WJ, Zouhair A, Mirimanoff RO, Azria D: CD4 and CD8 T-lymphocyte apoptosis can predict radiation-induced late toxicity: a prospective study in 399 patients. Clin Cancer Res 2005, 11:7426-7433

40. Finnon P, Robertson N, Dziwura S, Raffy C, Zhang W, Ainsbury L, Kaprio J, Badie C, Bouffler S: Evidence for significant heritability of apoptotic and cell cycle responses to ionising radiation. Hum Genet 2008, 123:485-493.

41. Roberts SA, Spreadborough AR, Bulman B, Barber JB, Evans DG, Scott D: Heritability of cellular radiosensitivity: a marker of low-penetrance predisposition genes in breast cancer? Am J Hum Genet 1999, 65:784-794.
42. Surowy H, Rinckleb A, Luedeke M, Stuber M, Wecker A, Varga D, Maier C, Hoegel J, Vogel W: Heritability of baseline and induced micronucleus frequencies. Mutagenesis 2011, 26:111-117.

43. Abbaszadeh F, Clingen PH, Arlett CF, Plowman PN, Bourton EC, Themis M, Makarov EM, Newbold RF, Green MH, Parris CN: A novel splice variant of the DNA-PKcs gene is associated with clinical and cellular radiosensitivity in a patient with xeroderma pigmentosum. J Med Genet 2010, 47:176-181.

44. Little JB, Nove J: Sensitivity of human diploid fibroblast cell strains from various genetic disorders to acute and protracted radiation exposure. Radiat Res 1990, 123:87-92.

45. Barnett GC, West CM, Dunning AM, Elliott RM, Coles CE, Pharoah PD, Burnet NG: Normal tissue reactions to radiotherapy: towards tailoring treatment dose by genotype. Nat Rev Cancer 2009, 9:134-142.

46. Taylor AM, Harnden DG, Arlett CF, Harcourt SA, Lehmann AR, Stevens S, Bridges BA: Ataxia telangiectasia: a human mutation with abnormal radiation sensitivity. Nature 1975, 258:427-429.

47. Kleinerman RA: Radiation-sensitive genetically susceptible pediatric subpopulations. Pediatr Radio/ 2009, 39 Suppl 1:S27-S31.

48. Tamulevicius $P$, Wang M, lliakis $\mathrm{G}$ : Homology-directed repair is required for the development of radioresistance during $\mathrm{S}$ phase: interplay between double-strand break repair and checkpoint response. Radiat Res 2007, 167:1-11.

49. Hendry JH, West CM: Apoptosis and mitotic cell death: their relative contributions to normal-tissue and tumour radiation response. Int J Radiat Biol 1997, 71:709-719.

50. Hoyes KP, Cai WB, Potten CS, Hendry JH: Effect of bcl-2 deficiency on the radiation response of clonogenic cells in small and large intestine, bone marrow and testis. Int J Radiat Bio/ 2000, 76:1435-1442.

51. Johnson SM, Torrice CD, Bell JF, Monahan KB, Jiang Q, Wang Y, Ramsey MR, Jin J, Wong KK, Su L, Zhou D, Sharpless NE: Mitigation of hematologic radiation toxicity in mice through pharmacological quiescence induced by CDK4/6 inhibition. J Clin Invest 2010, 120:2528-2536.

52. Kuptsova N, Chang-Claude J, Kropp S, Helmbold I, Schmezer P, von Fournier D, Haase W, Sautter-Bihl ML, Wenz F, Onel K, Ambrosone CB: Genetic predictors of long-term toxicities after radiation therapy for breast cancer. Int J Cancer 2008, 122:1333-1339.

53. Aykin-Burns N, Slane BG, Liu AT, Owens KM, O'Malley MS, Smith BJ, Domann FE, Spitz DR: Sensitivity to low-dose/low-LET ionizing radiation in mammalian cells harboring mutations in succinate dehydrogenase subunit $\mathrm{C}$ is governed by mitochondria-derived reactive oxygen species. Radiat Res 2011, 175:150-158.

54. Epperly MW, Epstein CJ, Travis EL, Greenberger JS: Decreased pulmonary radiation resistance of manganese superoxide dismutase (MnSOD)deficient mice is corrected by human manganese superoxide dismutasePlasmid/Liposome (SOD2-PL) intratracheal gene therapy. Radiat Res 2000, 154:365-374.

55. Tan W, Huang W, Zhong Q, Schwarzenberger P: IL-17 receptor knockout mice have enhanced myelotoxicity and impaired hemopoietic recovery following gamma irradiation. J Immuno/ 2006, 176:6186-6193.

56. Anscher MS: Targeting the TGF- $\beta 1$ pathway to prevent normal tissue injury after cancer therapy. Oncologist 2010, 15:350-359.

57. Von Pfeil A, Hakenjos L, Herskind C, Dittmann K, Weller M, Rodemann HP. Irradiated homozygous TGF- $\beta 1$ knockout fibroblasts show enhanced clonogenic survival as compared with TGF- $\beta 1$ wild-type fibroblasts. Int J Radiat Biol 2002, 78:331-339.

58. Finlay M, Laperriere N, Bristow RG: Radiotherapy and Marfan syndrome: a report of two cases. Clin Oncol (R Coll Radiol) 2005, 17:54-56.

59. Andreassen CN, Alsner J, Overgaard M, Sorensen FB, Overgaard J: Risk of radiation-induced subcutaneous fibrosis in relation to single nucleotide polymorphisms in TGFB1, SOD2, XRCC1, XRCC3, APEX and ATM - a study based on DNA from formalin fixed paraffin embedded tissue samples. Int J Radiat Biol 2006, 82:577-586.

60. Andreassen CN, Alsner J: Genetic variants and normal tissue toxicity after radiotherapy: a systematic review. Radiother Oncol 2009, 92:299-309.

61. Teo YY: Common statistical issues in genome-wide association studies: a review on power, data quality control, genotype calling and population structure. Curr Opin Lipidol 2008, 19:133-143.

62. Michikawa Y, Suga T, Ishikawa A, Hayashi H, Oka A, Inoko H, Iwakawa M, Imai T: Genome wide screen identifies microsatellite markers associated with acute adverse effects following radiotherapy in cancer patients. BMCMed Genet 2010, 11:123. 
63. Niu N, Qin Y, Fridley BL, Hou J, Kalari KR, Zhu M, Wu TY, Jenkins GD, Batzler A, Wang L: Radiation pharmacogenomics: a genome-wide association approach to identify radiation response biomarkers using human lymphoblastoid cell lines. Genome Res 2010, 20:1482-1492.

64. Manolio TA, Collins FS, Cox NJ, Goldstein DB, Hindorff LA, Hunter DJ, McCarthy MI, Ramos EM, Cardon LR, Chakravarti A, Cho JH, Guttmacher AE, Kong A, Kruglyak L, Mardis E, Rotimi CN, Slatkin M, Valle D, Whittemore AS, Boehnke M, Clark AG, Eichler EE, Gibson G, Haines JL, Mackay TF, McCarroll SA, Visscher PM: Finding the missing heritability of complex diseases. Nature 2009, 461:747-753

65. Morton LM, Chanock SJ: A step toward slaying the hydra of second cancers. NatMed 2011, 17:924-925.

66. West C, Rosenstein BS, Alsner J, Azria D, Barnett G, Begg A, Bentzen S, Burnet N, Chang-Claude J, Chuang E, Coles C, De Ruyck K, De Ruysscher D, Dunning A, Elliott R, Fachal L, Hall J, Haustermans K, Herskind C, Hoelscher T, Imai T, Iwakawa M, Jones D, Kulich C; EQUAL-ESTRO, Langendijk JH, O'Neils P, Ozsahin M, Parliament M, Polanski A, et al:: Establishment of a Radiogenomics Consortium. Int J Radiat Oncol Biol Phys 2010, 76:1295-1296.

67. Burnet NG, Elliott RM, Dunning A, West CM: Radiosensitivity, radiogenomics and RAPPER. Clin Oncol 2006, 18:525-528.

68. Ho AY, Atencio DP, Peters S, Stock RG, Formenti SC, Cesaretti JA, Green S, Haffty B, Drumea K, Leitzin L, Kuten A, Azria D, Ozsahin M, Overgaard J, Andreassen CN, Trop CS, Park J, Rosenstein BS: Genetic predictors of adverse radiotherapy effects: the Gene-PARE project. Int J Radiat Oncol Biol Phys 2006, 65:646-655

69. Suga T, Ishikawa A, Kohda M, Otsuka Y, Yamada S, Yamamoto N, Shibamoto Y, Ogawa Y, Nomura K, Sho K, Omura M, Sekiguchi K, Kikuchi Y, Michikawa Y, Noda S, Sagara M, Ohashi J, Yoshinaga S, Mizoe J, Tsujii H, Iwakawa M, Imai T: Haplotype-based analysis of genes associated with risk of adverse skin reactions after radiotherapy in breast cancer patients. Int J Radiat Oncol Biol Phys 2007, 69:685-693.

70. West CM, Elliott RM, Burnet NG: The genomics revolution and radiotherapy. Clin Oncol (R Coll Radiol) 2007, 19:470-480.

71. Valdagni R, Rancati T, Fiorino C: Predictive models of toxicity with external radiotherapy for prostate cancer: clinical issues. Cancer 2009, 115:3141-3149.

72. Dehing-Oberije C, De Ruysscher D, Petit S, Van Meerbeeck J, Vandecasteele K, De Neve W, Dingemans AM, El Naqa I, Deasy J, Bradley J, Huang E, Lambin P. Development, external validation and clinical usefulness of a practical prediction model for radiation-induced dysphagia in lung cancer patients. Radiother Oncol 2010, 97:455-461.

73. Janssens AC, van Duijn CM: Genome-based prediction of common diseases: advances and prospects. Hum Mol Genet 2008, 17:R166-R173.

74. Guessous I, Gwinn M, Khoury MJ: Genome-wide association studies in pharmacogenomics: untapped potential for translation. Genome Med 2009, $1: 46$.

75. GoDARTS and UKPDS Diabetes Pharmacogenetics Study Group; Wellcome Trust Case Control Consortium 2, Zhou K, Bellenguez C, Spencer CC, Bennett AJ, Coleman RL, Tavendale R, Hawley SA, Donnelly LA, Schofield C, Groves CJ, Burch L, Carr F, Strange A, Freeman C, Blackwell JM, Bramon E, Brown MA, Casas JP, Corvin A, Craddock N, Deloukas P, Dronov S, Duncanson A, Edkins S, Gray E, Hunt S, Jankowski J, Langford C, et al:: Common variants near ATM are associated with glycemic response to metformin in type 2 diabetes. Nat Genet 2011 43:117-120.

76. Curwen GB, Winther JF, Tawn EJ, Smart V, Whitehouse CA, Rees GS, Olsen JH, Guldberg P, Rechnitzer C, Schrøder H, Bryant PE, Sheng X, Lee HS, Chakraborty R, Boice JD: G(2) chromosomal radiosensitivity in Danish survivors of childhood and adolescent cancer and their offspring. $\mathrm{Br} J$ Cancer 2005, 93:1038-1045.

77. Wu X, Spitz MR, Amos Cl, Lin J, Shao L, Gu J, de Andrade M, Benowitz NL, Shields PG, Swan GE: Mutagen sensitivity has high heritability: evidence from a twin study. Cancer Res 2006, 66:5993-5996.

78. Schmitz A, Bayer J, Dechamps N, Goldin L, Thomas G: Heritability of susceptibility to ionizing radiation-induced apoptosis of human lymphocyte subpopulations. Int J Radiat Oncol Biol Phys 2007, 68:1 169-1177.

79. Curwen GB, Cadwell KK, Winther JF, Tawn EJ, Rees GS, Olsen JH, Rechnitzer C, Schroeder H, Guldberg P, Cordell HJ, Boice JD Jr: The heritability of G2 chromosomal radiosensitivity and its association with cancer in Danish cancer survivors and their offspring. Int J Radiat Biol 2010, 86:986-995.

80. Jeggo P, Lavin MF: Cellular radiosensitivity: how much better do we understand it? Int J Radiat Biol 2009, 85:1061-1081.
81. Matsumoto Y, Miyamoto T, Sakamoto H, Izumi H, Nakazawa Y, Ogi T, Tahara H, Oku S, Hiramoto A, Shiiki T, Fujisawa Y, Ohashi H, Sakemi Y, Matsuura S: Two unrelated patients with MRE11A mutations and Nijmegen breakage syndrome-like severe microcephaly. DNA Repair 2011, 10:314-321.

82. O'Driscoll M, Gennery AR, Seidel J, Concannon P, Jeggo PA: An overview of three new disorders associated with genetic instability: LIG4 syndrome, RS-SCID and ATR-Seckel syndrome. DNA Repair 2004, 3:1227-1235.

83. Chistiakov DA, Voronova NV, Chistiakov PA: Genetic variations in DNA repair genes, radiosensitivity to cancer and susceptibility to acute tissue reactions in radiotherapy-treated cancer patients. Acta Onco/ 2008, 47:809-824.

84. Waltes R, Kalb R, Gatei M, Kijas AW, Stumm M, Sobeck A, Wieland B, Varon R, Lerenthal Y, Lavin MF, Schindler D, Dörk T: Human RAD50 deficiency in a Nijmegen breakage syndrome-like disorder. Am J Hum Genet 2009, 84:605-616.

85. Stewart GS, Stankovic T, Byrd PJ, Wechsler T, Miller ES, Huissoon A, Drayson MT, West SC, Elledge SJ, Taylor AM: RIDDLE immunodeficiency syndrome is linked to defects in 53BP1-mediated DNA damage signaling. Proc Natl Acad Sci U S A 2007, 104:16910-16915.

86. Revenkova E, Focarelli ML, Susani L, Paulis M, Bassi MT, Mannini L, Frattini A Delia D, Krantz I, Vezzoni P, Jessberger R, Musio A: Cornelia de Lange syndrome mutations in SMC1A or SMC3 affect binding to DNA. Hum Mol Genet 2009, 18:418-427.

87. Yoon HH, Catalano P, Gibson MK, Skaar TC, Philips S, Montgomery EA, Hafez MJ, Powell M, Liu G, Forastiere AA, Benson AB, Kleinberg LR, Murphy KM: Genetic variation in radiation and platinum pathways predicts severe acute radiation toxicity in patients with esophageal adenocarcinoma treated with cisplatin-based preoperative radiochemotherapy: results from the Eastern Cooperative Oncology Group. Cancer Chemother Pharmacol, in press.

88. Yang M, Zhang L, Bi N, Ji W, Tan W, Zhao L, Yu D, Wu C, Wang L, Lin D: Association of $P 53$ and ATM polymorphisms with risk of radiation-induced pneumonitis in lung cancer patients treated with radiotherapy. Int J Radiat Oncol Biol Phys 2011, 79:1402-1407.

89. Langsenlehner T, Renner W, Gerger A, Hofmann G, Thurner EM, Kapp KS, Langsenlehner $\mathrm{U}$ : Association between single nucleotide polymorphisms in the gene for XRCC1 and radiation-induced late toxicity in prostate cancer patients. Radiother Oncol 2011, 98:387-393.

90. Mangoni M, Bisanzi S, Carozzi F, Sani C, Biti G, Livi L, Barletta E, Costantini AS, Gorini G: Association between genetic polymorphisms in the XRCC1, XRCC3, XPD, GSTM1, GSTT1, MSH2, MLH1, MSH3, and MGMT genes and radiosensitivity in breast cancer patients. Int J Radiat Oncol Biol Phys, in press.

91. Hildebrandt MA, Komaki R, Liao Z, Gu J, Chang JY, Ye Y, Lu C, Stewart DJ, Minna JD, Roth JA, Lippman SM, Cox JD, Hong WK, Spitz MR, Wu X: Genetic variants in inflammation-related genes are associated with radiationinduced toxicity following treatment for non-small cell lung cancer. Plos One 2010, 5:e12402.

92. Sterpone S, Cornetta T, Padua L, Mastellone V, Giammarino D, Testa A, Tirindelli D, Cozzi R, Donato V: DNA repair capacity and acute radiotherapy adverse effects in Italian breast cancer patients. Mutat Res 2010, 684:43-48.

93. Alsbeih G, Al-Harbi N, Al-Hadyan K, El-Sebaie M, Al-Rajhi N: Association between normal tissue complications after radiotherapy and polymorphic variations in TGFB1 and XRCC1 genes. Radiat Res 2010, 173:505-511.

94. Zhou L, Xia J, Li H, Dai J, Hu Y: Association of XRCC1 variants with acute skin reaction after radiotherapy in breast cancer patients. Cancer Biother Radiopharm 2010, 25:681-685.

95. Zhang L, Yang M, Bi N, Ji W, Wu C, Tan W, Zhao L, Yu D, Lin D, Wang L: Association of TGF- $\beta 1$ and XPD polymorphisms with severe acute radiation-induced esophageal toxicity in locally advanced lung cancer patients treated with radiotherapy. Radiother Oncol 2010, 97:19-25.

96. Zschenker O, Raabe A, Boeckelmann IK, Borstelmann S, Szymczak S, Wellek S, Rades D, Hoeller U, Ziegler A, Dikomey E, Borgmann K: Association of single nucleotide polymorphisms in ATM, GSTP1, SOD2, TGFB1, XPD and XRCC1 with clinical and cellular radiosensitivity. Radiother Onco/ 2010, 97:26-32.

97. Ishikawa A, Suga T, Shoji Y, Kato S, Ohno T, Ishikawa H, Yoshinaga S, Ohara K, Ariga H, Nomura K, Shibamoto Y, Ishikawa Kl, Moritake T, Michikawa Y, I wakawa M, Imai T: Genetic variants of NPAT-ATM and AURKA are associated with an early adverse reaction in the gastrointestinal tract of patients with cervical cancer treated with pelvic radiation therapy. Int J Radiat Oncol Biol Phys, in press. 
98. Martin S, Sydenham M, Haviland J, A'Hern R, Owen R, Bliss J, Yarnold J: Test of association between variant tgbeta1 alleles and late adverse effects of breast radiotherapy. Radiother Oncol 2010, 97:15-18.

99. Barnett GC, Coles CE, Burnet NG, Pharoah PD, Wilkinson J, West CM, Elliott RM, Baynes C, Dunning AM: No association between SNPs regulating TGF-beta1 secretion and late radiotherapy toxicity to the breast: results from the RAPPER study. Radiother Oncol 2010, 97:9-14.

100. Fogarty GB, Muddle R, Sprung CN, Chen W, Duffy D, Sturm RA, McKay MJ: Unexpectedly severe acute radiotherapy side effects are associated with single nucleotide polymorphisms of the melanocortin-1 receptor. Int J Radiat Oncol Biol Phys 2010, 77:1486-1492.

101. Chang-Claude J, Ambrosone CB, Lilla C, Kropp S, Helmbold I, von Fournier D, Haase W, Sautter-Bihl ML, Wenz F, Schmezer P, Popanda O: Genetic polymorphisms in DNA repair and damage response genes and late normal tissue complications of radiotherapy for breast cancer. $\mathrm{Br} J \mathrm{Cancer}$ 2009, 100:1680-1686.

102. Yuan X, Liao Z, Liu Z, Wang LE, Tucker SL, Mao L, Wang XS, Martel M, Komaki R, Cox JD, Milas L, Wei Q: Single nucleotide polymorphism at rs 1982073:T869C of the TGFbeta 1 gene is associated with the risk of radiation pneumonitis in patients with non-small-cell lung cancer treated with definitive radiotherapy. J Clin Onco/ 2009, 27:3370-3378.

103. Werbrouck J, De Ruyck K, Duprez F, Veldeman L, Claes K, Van Eijkeren M, Boterberg T, Willems P, Vral A, De Neve W, Thierens H: Acute normal tissue reactions in head-and-neck cancer patients treated with IMRT: influence of dose and association with genetic polymorphisms in DNA DSB repair genes. Int J Radiat Oncol Biol Phys 2009, 73:1187-1195.

104. Popanda O, Marquardt JU, Chang-Claude J, Schmezer P: Genetic variation in normal tissue toxicity induced by ionizing radiation. Mutat Res 2009, 667:58-69.

105. Meyer A, Dörk T, Bogdanova N, Brinkhaus MJ, Wiese B, Hagemann J, Serth J, Bremer M, Baumann R, Karstens JH, Machtens S: TGFB1 gene polymorphism Leu10Pro (c.29T>C), prostate cancer incidence and quality of life in patients treated with brachytherapy. World J Urol 2009, 27:371-377.

106. Langsenlehner T, Kapp KS, Langsenlehner U: TGFB1 single-nucleotide polymorphisms are associated with adverse quality of life in prostate cancer patients treated with radiotherapy. In regard to Peters et al. (Int J Radiat Oncol Biol Phys 2008;70:752-759). Int J Radiat Oncol Biol Phys 2008, 71:960; author reply 960-961.

107. Peters CA, Stock RG, Cesaretti JA, Atencio DP, Peters S, Burri RJ, Stone NN, Ostrer $\mathrm{H}$, Rosenstein BS: TGFB1 single nucleotide polymorphisms are associated with adverse quality of life in prostate cancer patients treated with radiotherapy. Int J Radiat Oncol Biol Phys 2008, 70:752-759.

108. Isomura M, Oya N, Tachiiri S, Kaneyasu Y, Nishimura Y, Akimoto T, Hareyama M, Sugita T, Mitsuhashi N, Yamashita T, Aoki M, Sai H, Hirokawa Y, Sakata K, Karasawa K, Tomida A, Tsuruo T, Miki Y, Noda T, Hiraoka M: IL12RB2 and $A B C A 1$ genes are associated with susceptibility to radiation dermatitis. Clin Cancer Res 2008, 14:6683-6689.

109. Burri RJ, Stock RG, Cesaretti JA, Atencio DP, Peters S, Peters CA, Fan G, Stone $\mathrm{NN}$, Ostrer $\mathrm{H}$, Rosenstein BS: Association of single nucleotide polymorphisms in SOD2, XRCC1 and XRCC3 with susceptibility for the development of adverse effects resulting from radiotherapy for prostate cancer. Radiat Res 2008, 170:49-59.

110. Badie C, Dziwura S, Raffy C, Tsigani T, Alsbeih G, Moody J, Finnon P, Levine E, Scott D, Bouffler S: Aberrant CDKN1A transcriptional response associates with abnormal sensitivity to radiation treatment. Br J Cancer 2008, 98:1845-1851.

111. Suga T, Iwakawa M, Tsuji H, Ishikawa H, Oda E, Noda S, Otsuka Y, Ishikawa A, Ishikawa K, Shimazaki J, Mizoe JE, Tsujii H, Imai T: Influence of multiple genetic polymorphisms on genitourinary morbidity after carbon ion radiotherapy for prostate cancer. Int J Radiat Oncol Biol Phys 2008, 72:808-813

112. Giotopoulos G, Symonds RP, Foweraker K, Griffin M, Peat I, Osman A, Plumb $\mathrm{M}$ : The late radiotherapy normal tissue injury phenotypes of telangiectasia, fibrosis and atrophy in breast cancer patients have distinct genotype-dependent causes. Br J Cancer 2007, 96:1001-1007.

113. Edvardsen H, Tefre T, Jansen L, Vu P, Haffty BG, Fossa SD, Kristensen VN, Borresen-Dale AL: Linkage disequilibrium pattern of the ATM gene in breast cancer patients and controls; association of SNPs and haplotypes to radio-sensitivity and post-lumpectomy local recurrence. Radiat Oncol 2007, 2:25.

114. Edvardsen H, Kristensen VN, Grenaker Alnaes GI, Bohn M, Erikstein B, Helland
A, Borresen-Dale AL, Fossa SD: Germline glutathione S-transferase variants in breast cancer: relation to diagnosis and cutaneous long-term adverse effects after two fractionation patterns of radiotherapy. Int J Radiat Oncol Biol Phys 2007, 67:1163-1171.

115. Ahn J, Ambrosone CB, Kanetsky PA, Tian C, Lehman TA, Kropp S, Helmbold I, von Fournier D, Haase W, Sautter-Bihl ML, Wenz F, Chang-Claude J: Polymorphisms in genes related to oxidative stress (CAT, MnSOD, MPO, and eNOS) and acute toxicities from radiation therapy following lumpectomy for breast cancer. Clin Cancer Res 2006, 12:7063-7070

116. Brem R, Cox DG, Chapot B, Moullan N, Romestaing P, Gerard JP, Pisani P, Hall J: The XRCC1 -77T->C variant: haplotypes, breast cancer risk, response to radiotherapy and the cellular response to DNA damage. Carcinogenesis 2006, 27:2469-2474.

117. Tan XL, Popanda O, Ambrosone CB, Kropp S, Helmbold I, von Fournier D, Haase W, Sautter-Bihl ML, Wenz F, Schmezer P, Chang-Claude J: Association between TP53 and p21 genetic polymorphisms and acute side effects of radiotherapy in breast cancer patients. Breast Cancer Res Treat 2006, 97:255-262.

118. Popanda O, Tan XL, Ambrosone CB, Kropp S, Helmbold I, von Fournier D, Haase W, Sautter-Bihl ML, Wenz F, Schmezer P, Chang-Claude J: Genetic polymorphisms in the DNA double-strand break repair genes $\mathrm{XRCC} 3$, $X R C C 2$, and NBS1 are not associated with acute side effects of radiotherapy in breast cancer patients. Cancer Epidemiol Biomarkers Prev 2006, 15:1048-1050.

119. De Ruyck K, Van Eijkeren M, Claes K, Bacher K, Vral A, De Neve W, Thierens H: TGFbeta1 polymorphisms and late clinical radiosensitivity in patients treated for gynecologic tumors. Int J Radiat Oncol Biol Phys 2006, 65:1240-1248

120. Damaraju S, Murray D, Dufour J, Carandang D, Myrehaug S, Fallone G, Field C, Greiner R, Hanson J, Cass CE, Parliament M: Association of DNA repair and steroid metabolism gene polymorphisms with clinical late toxicity in patients treated with conformal radiotherapy for prostate cancer. Clin Cancer Res 2006, 12:2545-2554.

121. Ambrosone CB, Tian C, Ahn J, Kropp S, Helmbold I, von Fournier D, Haase W, Sautter-Bihl ML, Wenz F, Chang-Claude J: Genetic predictors of acute toxicities related to radiation therapy following lumpectomy for breast cancer: a case-series study. Breast Cancer Res 2006, 8:R40.

122. Kornguth DG, Garden AS, Zheng Y, Dahlstrom KR, Wei Q, Sturgis EM: Gastrostomy in oropharyngeal cancer patients with ERCC4 (XPF) germline variants. Int J Radiat Oncol Biol Phys 2005, 62:665-671.

123. Chang-Claude J, Popanda O, Tan XL, Kropp S, Helmbold I, von Fournier D, Haase W, Sautter-Bihl ML, Wenz F, Schmezer P, Ambrosone CB: Association between polymorphisms in the DNA repair genes, XRCC1, APE1, and XPD and acute side effects of radiotherapy in breast cancer patients. Clin Cancer Res 2005, 11:4802-4809.

124. Andreassen CN, Alsner J, Overgaard J, Herskind C, Haviland J, Owen R, Homewood J, Bliss J, Yarnold J: TGFB1 polymorphisms are associated with risk of late normal tissue complications in the breast after radiotherapy for early breast cancer. Radiother Oncol 2005, 75:18-21.

125. De Ruyck K, Wilding CS, Van Eijkeren M, Morthier R, Tawn EJ, Thierens H: Microsatellite polymorphisms in DNA repair genes $\mathrm{XRCC} 1, \mathrm{XRCC} 3$ and $\mathrm{XRCC5}$ in patients with gynecological tumors: association with late clinical radiosensitivity and cancer incidence. Radiat Res 2005, 164:237-244.

126. Moullan N, Cox DG, Angele S, Romestaing P, Gerard JP, Hall J: Polymorphisms in the DNA repair gene XRCC1, breast cancer risk, and response to radiotherapy. Cancer Epidemiol Biomarkers Prev 2003, 12:1168-1174.

127. Quarmby S, Fakhoury H, Levine E, Barber J, Wylie J, Hajeer AH, West C, Stewart A, Magee B, Kumar S: Association of transforming growth factor beta-1 single nucleotide polymorphisms with radiation-induced damage to normal tissues in breast cancer patients. Int J Radiat Bio/ 2003, 79:137-143.

128. Andreassen CN, Alsner J, Overgaard M, Overgaard J: Prediction of normal tissue radiosensitivity from polymorphisms in candidate genes. Radiother Oncol 2003, 69:127-135

129. Angèle $S$, Romestaing $P$, Moullan $N$, Vuillaume $M$, Chapot $B$, Friesen $M$, Jongmans W, Cox DG, Pisani P, Gérard JP, Hall J: ATM haplotypes and cellular response to DNA damage: association with breast cancer risk and clinical radiosensitivity. Cancer Res 2003, 63:8717-8725.

130. Green H, Ross G, Peacock J, Owen R, Yarnold J, Houlston R: Variation in the manganese superoxide dismutase gene (SOD2) is not a major cause of radiotherapy complications in breast cancer patients. Radiother Onco/ 2002, 63:213-216. 
131. Severin DM, Leong T, Cassidy B, Elsaleh H, Peters L, Venter D, Southey M, McKay M: Novel DNA sequence variants in the hHR21 DNA repair gene in radiosensitive cancer patients. Int J Radiat Oncol Biol Phys 2001, 50:1323-1331.

132. Bhatti S, Kozlov S, Farooqi AA, Naqi A, Lavin M, Khanna KK: ATM protein kinase: the linchpin of cellular defenses to stress. Cell Mol Life Sci, in press.

133. Malaise EP, Fertil B, Deschavanne PJ, Chavaudra N, Brock WA: Initial slope of radiation survival curves is characteristic of the origin of primary and established cultures of human tumor cells and fibroblasts. Radiat Res 1987, 111:319-333.
134. West CM, Davidson SE, Elyan SA, Valentine H, Roberts SA, Swindell R, Hunter $\mathrm{RD}$ : Lymphocyte radiosensitivity is a significant prognostic factor for morbidity in carcinoma of the cervix. Int J Radiat Oncol Biol Phys 2001, 51:10-15.

doi:10.1186/gm268

Cite this article as: West CM, Barnett GC: Genetics and genomics of radiotherapy toxicity: towards prediction. Genome Medicine 2011, 3:52. 